\title{
Is Ecuador That Wrong?: Analyzing the Ecuadorian Proposals Concerning the Special Rapporteurship on Freedom of Expression of the Inter-American Commission on Human Rights
}

\author{
by Oswaldo R. Ruiz-Chiriboga*
}

\section{INTRODUCTION}

$\mathrm{I}$ n June 2011, the Permanent Council of the Organization of American States (OAS), following the instructions given during the 41st regular session of the General Assembly of the OAS, decided to create a "Special Working Group to Reflect on the Workings of the Inter-American Commission on Human Rights with a View to Strengthening the Inter-American Human Rights System" (Working Group). The Permanent Council directed the Working Group to submit its final recommendations at the Council's regular meeting in December 2011. ${ }^{1}$

In the course of the 23 meetings the Working Group held during six months of passionate debate, it focused its attention on eight topics: 1) the appointment of the next Executive Secretary of the Inter-American Commission; 2) challenges and medium and long-term objectives of the Commission; 3) precautionary measures; 4) procedural matters in processing cases and individual petitions; 5) friendly settlements; 6) criteria for constructing Chapter IV of the Commission's Annual Report; 7) promotion of human rights; and 8) financially strengthening the InterAmerican Human Rights System. ${ }^{2}$

\footnotetext{
* Doctoral researcher, Human Rights Centre, Department of Public Law, Ghent University; L.L.M. in International Human Rights and Criminal Justice (Utrecht University); L.L.M. in International Criminal Law (Granada University); Postgraduate Degree in Legal Argumentation (Alicante University); Postgraduate Degree in Human Rights (Andean University Simón Bolivar); Postgraduate Degree in Human Rights and Democracy (Pontifical Catholic University of Ecuador); former Senior Staff Attorney of the Inter-American Court of Human Rights. The author owes special thanks to Prof. Dr. Yves Haeck (Ghent University), Francisco J. Rivera Juaristi (Santa Clara University), and the editors of the Human Rights Brief for their thoughtful comments and editorial review. Of course, the author assumes personal responsibility for any remaining errors. He can be contacted at Oswaldo.RuizChiriboga@UGent.be or through his blog at http://corteidhblog.blogspot.com.
}

The Working Group opened its meetings to delegations from all OAS Member States and received presentations that were subsequently published in a combined document. ${ }^{3}$ The States were also allowed to submit proposals. ${ }^{4}$ Furthermore, the Group received recommendations from the Secretary General of the OAS and from civil society organizations. ${ }^{5}$ The Commission had the opportunity to attend all meetings.

The creation of the Working Group was viewed with suspicion by the Commission and by many civil society organizations because it was considered a reaction of the States to several "uncomfortable" decisions adopted by the Commission. The Working Group's true intention was, according to some, to weaken the system of protection and to silence or control the Commission, affecting its independence and impartiality. ${ }^{6}$ The Ecuadorian proposals were viewed as an example of such intention, the most controversial being the ones related to the Commission's rapporteurships. ${ }^{7}$ 
consideration within six months or no later than the first quarter of $2013 .^{12}$

The current Ecuadorian government has been accused of attacking freedom of expression and having a hostile relationship with the press, the SRFE, and the Commission, but apart from the government's potential political motivations, does Ecuador have a point? Is there an imbalance in the attention the Commission devotes to the right to freedom of expression, or is this only a delusional idea of an upset government? If such distinction truly exists, is Ecuador correct when it denounces a lack of independence or impartiality of the Commission? ${ }^{13}$ In order to answer these questions, a brief analysis of the Commission's rapporteurships is needed.

\section{The Commission's Rapporteurships}

The Commission's rapporteurships are classified by country, theme, and type. Country rapporteurs monitor the human rights situation of a specific country. According to the Commission's Rules of Procedure, it may designate its commissioners as country rapporteurs, "in which case the Commission will ensure that each Member State of the OAS has a rapporteur." 14 The Rules of Procedures strive for a balance in the attention the Commission gives to all the countries in the region. All 35 OAS Member States have a country rapporteur.

The Commission may also create rapporteurships to cover areas "deemed of special interest." 15 These are called thematic rapporteurships. So far the Commission has created eight such rapporteurships: indigenous people, women, migrant workers, freedom of expression, children, human rights defenders, persons deprived of liberty, and Afro-descendants.

Finally, there are two types of rapporteurships: regular and special. Regular rapporteurships are the ones assigned to a Commissioner, that is to say, to persons elected by the General Assembly of the OAS as members of the Commission for a renewable term of four years. Conversely, special rapporteurships are assigned to other persons designated by the Commission. Special rapporteurs are not commissioners since they were not elected by the General Assembly. So far the Commission has only created one special rapporteurship: the SRFE.

\section{The Special Rapporteurship on Freedom of EXPRESSION}

The Commission created the SRFE during its 97th period of sessions, held in October 1997, with the purpose of "strengthening the capacity of the [Commission] to promote and protect full observance of this important right in the Americas, and thus help to ensure its effective exercise." 16

Whether the Commission had the power to create the SRFE is an issue that deserves further research. The American Convention on Human Rights ${ }^{17}$ and the Statute of the Commission, ${ }^{18}$ both instruments adopted by the General Assembly of the OAS, do not explicitly mention this power. The only instrument that gives explicit legal support to this type of rapporteurship is the Rules of Procedure of the Commission, which the Commission itself adopted, not the OAS Member States. The Commission's initiative to create the SRFE, however, was supported by
Member States. ${ }^{19}$ The question then is not whether the States supported the creation of the SRFE but whether this support was required for the SRFE's functioning or as an approval of the Commission's decision. It seems that the Commission does not consider the support of the States necessary in either of these senses. According to its Rules of Procedure, the creation of special rapporteurships is a decision of the Commission and the Commission alone. States are not even informed of this decision. They will find out that a new special rapporteurship will be created when the Commission makes a call to fill the vacancy. ${ }^{20}$

Another issue that deserves further research is the binding power of the recommendations and conclusions of special rapporteurs. Since they are not commissioners, their remarks should not have the same binding power as those of the commissioners (whatever this might be). Usually, the conclusions of the SRFE are later approved or otherwise supported by the Commission, but this is not always the case. The SRFE issues documents, such as press releases, where it presents its observations as an office of the Commission but without mentioning whether the Commission agrees.

As to the creation of the SRFE, two questions arise: 1) why did the Commission decide to create this particular rapporteurship, and 2) why did it decide that the rapporteurship should be special?

\section{The Decision to Create the SRFE}

The only explanation given by the Commission for its decision to create the SRFE was that the right to freedom of expression is an important right in the Americas that needed to be promoted, protected, and whose effective exercise needed to be ensured. ${ }^{21}$ But the same explanation could be given for any other right. The rights to freedom of association, freedom of religion, social rights, and basically all other human rights are also important rights in the Americas that need promotion and protection.

\section{The "Special" Character of the SRFE}

At the time the SFRE was created there were only three regular thematic rapporteurships: indigenous peoples, women, and migrant workers. In other words, only three of the seven commissioners were assigned a thematic rapporteurship; the other four commissioners acted only as country rapporteurs. Why the Commission decided to hire an outside expert as a special rapporteur, when four of its members could have easily assumed the new rapporteurship of freedom of expression as a regular rapporteur, is a question the Commission has not answered.

Furthermore, the Commission seems to have no uniform criteria for the creation of rapporteurships and their mandates.

\section{Different Process of Creation}

Although the SRFE was created from the beginning as a special rapporteurship, other rapporteurships had to transit a more difficult road. That is the case of the Rapporteurship on Human Rights Defenders, which started in 2001 as a "unit" under the framework of the Commission's Executive Secretariat. Only after ten years of gathering information 
and receiving several requests from civil society organizations was it "promoted" to a regular rapporteurship, but not to a special rapporteurship, despite the fact that human rights defenders face a critical situation in the Americas. ${ }^{22}$ All the rapporteurships that followed (children, persons deprived of liberty, and Afro-descendants) are also regular rapporteurships.

\section{Different Types of Mandates}

The SRFE is the only rapporteurship devoted to a specific right, with all others rapporteurships devoted to groups in a situation of vulnerability. Although journalists could be considered a group at risk in certain countries in the region, the SRFE is not a rapporteurship on journalists. It studies all the aspects of the right to freedom of expression, including but not limited to journalists' rights. ${ }^{23}$ Why the Commission decided to create a rapporteurship that monitors only one right, while all the other rapporteurships monitor the rights of individuals in a vulnerable situation, is an unanswered question. Moreover, other vulnerable groups, such as persons with disabilities, the elderly, LGTBI communities, and people with HIV/AIDS do not have a rapporteurship. ${ }^{24}$

Having a rapporteurship on a right (whatever this is), instead of a rapporteurship on individuals in vulnerable situations, is not an irrelevant issue. If we accept that all human rights are supposed to be indivisible and interdependent, ${ }^{25}$ the natural consequence is that there is no hierarchy of rights because every right is as important as the others. ${ }^{26}$ Giving extra protection to one right over others could be read as de facto hierarchization. This does not mean that the Commission should never create rapporteurships on specific rights. It only means that if a right is going to have a special mechanism of protection, such as a special rapporteurship, compelling reasons should justify the prioritization and such prioritization should not be indefinite. On the contrary, persons in a situation of vulnerability are "segments of the population which are or should be the recipients of extra care and attention," 27 which mandates particular attention of States but also of international bodies like the Commission. Vulnerability does not focus on the right itself but on the holders of that right, who for one reason or another cannot exercise that right as freely as others, or who suffer a greater risk of infringement of that right.

The points presented so far should not be read as a false dichotomy that either the Commission must create rapporteurships concerning each and every vulnerable group and/or right, or it must not create any rapporteurship concerning any particular group and/or right. The Commission does not have enough resources to cover everything, and even if it did, creating a rapporteurship for each right or group could be unnecessary. Rather, the Commission should explain why it decided to create this particular rapporteurship and why it should be special. If a rapporteurship is going to cover the rights of persons in a situation of vulnerability, the explanation of the Commission is much easier: vulnerable persons need special protection. A more detailed explanation is needed if the new rapporteurship is going to cover a right. All human rights are equally important but in certain scenarios, some rights might be in a greater danger of infringement. The Commission has failed to explain why freedom of expression needs special protection over other rights and, moreover, why this right has a rapporteurship with many more privileges that the other rapporteurships.

\section{The Special Privileges of the Special Rapporteurship}

Being a special rapporteurship brings along a number of benefits that regular rapporteurships do not have, for instance:

1. The head of the SRFE, the Special Rapporteur, works on a full-time basis. The Special Rapporteur has a permanent office at the seat of the Commission. Regular rapporteurs, that is to say, the commissioners, work on a part-time basis. They meet a couple of times per year during the Commission's periods of sessions.

2. The staff of the SRFE is composed of the Special Rapporteur, one project development specialist, three human rights specialists, one press coordinator, and one administrative assistant. ${ }^{28}$ This is an A-team that other rapporteurships do not have. For instance, the Rapporteurship on Migrant Workers has a part-time Rapporteur and one human rights specialist. ${ }^{29}$

3. The one and only concern of the SRFE is the right to freedom of expression. Regular rapporteurs must divide their attention between their country and thematic rapporteurships, plus their regular duties as commissioners. For instance, Commissioner Dinah Shelton, former President of the Commission, had to divide her time between her duties as President, her duties as Commissioner, her duties as Rapporteur of Antigua and Barbuda, Barbados, Bahamas, Belize, Dominica, Ecuador, Grenada, Guatemala, Guyana, Jamaica, St. Kitts and Nevis, St. Lucia, St. Vincent and the Grenadines, Suriname, and Trinidad and Tobago, and her duties as Rapporteur on Indigenous Peoples. ${ }^{30}$

4. The SRFE is the only rapporteurship that presents a separate annual report to the OAS General Assembly. The reports of the regular rapporteurships are included in the Commission's Annual Report. In 2010 the section of the Commission's Annual Report reserved for the regular rapporteurships' reports contained 10 pages, an average of 1.4 pages for each regular rapporteurship. ${ }^{31}$ Conversely, the annual report of the SRFE contained 415 pages. ${ }^{32}$

5. The SRFE is financed wholly through external funds specifically donated for this purpose by States from both inside and outside the region, as well as private donors. For reasons that need further research, the SRFE budget is considerably larger than those of other rapporteurships. For 2010, the SRFE had projects for approximately USD \$1.7 million. This is 3.09 times the budget of the Rapporteurship on Women's Rights (\$556,350); 3.77 times the budget of the Rapporteurship on Indigenous Peoples $(\$ 453,000) ; 5$ 
times the budget of the Rapporteurship on Persons Deprived of Their Liberty $(\$ 349,498) ; 5.86$ times the budget of the Rapporteurship on Migrant Workers $(\$ 299,624)$; and 17 times the budget of the Rapporteurship on the Rights of the Child (\$105,969)..$^{33}$

One may say that some of the facts presented above are merely administrative issues that do not raise juridical issues, but as will be explained latter, the favoritism to one right does have implications for States, victims, and the Commission itself. Before that, the prospects for the future shall be considered.

\section{Prospects for the Future}

The prospects for the near-future do not seem to suggest that there will be any changes in the preferential treatment freedom of expression receives. According to the Commission's Strategic Plan 2011-2015, the SRFE's activities will greatly exceed those of the other rapporteurships. ${ }^{34}$ The Commission's plans are:

1. to hold twenty thematic hearings per year, which means that each regular rapporteurship will have approximately three hearings per year — during the same period, the SRFE plans to have ten hearings on freedom of expression;

2. to issue a report on each of the seven thematic areas every eighteen months - the SRFE will continue to issue a report on freedom of expression every twelve months;

3. to send eight cases to the Inter-American Court of Human Rights - the SRFE has the goal of moving at least nine cases per year through the System;

4. each regular rapporteur will make one working visit per year to countries in the region - the SRFE plans two visits per year to assess the situation regarding freedom of expression;

5. finally, the SRFE plans to give thirty seminars in fifteen different countries for journalists, academics and other members of civil society - there is no mention that other rapporteurships will conduct seminars on their thematic areas.

This imbalance brings to mind at least two questions: a) what are the consequences of giving preferential treatment to one right, and b) why does the SRFE have the budget necessary to conduct all its previous and future activities.

\section{The Consequences of Having a Preferential Right}

Giving preferential treatment to the right to freedom of expression has consequences. Firstly, since the situation of freedom of expression is not the same throughout the region, because some countries have more problems than others, the countries with doubtful records on freedom of expression feel targeted by the Commission. They would rather have an active rapporteurship on thematic areas in which they think they have better records. Such rapporteurships would thus focus on other countries that have worse records in those thematic areas. No state likes to be singled out. This may be the case of Ecuador and, therefore, those that argue that the true intentions of Ecuador are to stop the Commission from focusing on the country may not be entirely wrong. However, this is not the only consequence. A second result of the preferential treatment affects the victims of violations of other rights. As seen above, victims belonging to groups in a situation of vulnerability covered by the other thematic rapporteurships of the Commission have fewer chances that their cases will be heard by the Court, there will be fewer hearings, fewer in situ visits, less visibility in the Commission's Annual Report, and so on. The right to freedom of expression becomes the king of the rights in the Americas, protecting a limited number of victims from a limited number of states.

It should also be noted that freedom of expression is already a directly enforceable right in the Inter-American System through the mechanism of individual petitions. Victims alleging the violation of this right can submit a complaint directly to the Commission, and the Commission may refer the case to the Court. Other rights, namely most of the economic, social, and cultural (ESC) rights are not directly enforceable. The only mechanism designed for their protection is the system of periodic reports States present to the Commission on regular a basis. ${ }^{35}$ If any group of rights requires special protection, that group should be ESC rights. The Commission, however, does not have a regular nor a special rapporteurship dedicated to monitor the compliance of ESC rights obligations. The Commission's regular rapporteurships sometimes study the ESC rights of the vulnerable groups they cover, but again, regular rapporteurships have less financial and human resources that the SRFE.

\section{The SRFE's Bigger Budget}

As mentioned before, the question of the SRFE's budget needs further research, but two preliminary reasons for its size could be advanced. On the one hand, the success of the SRFE in its fund-raising could be explained by the fact that it is the only rapporteurship with full-time personnel. This allows the Special Rapporteur to dedicate much more time to look for donors to increase the budget of the office. Current and former special rapporteurs on freedom of expression were very active and committed to their work, so the person in charge of the office also makes a big difference. Nonetheless, one question arises here: if the creation of a special rapporteurship on freedom of expression was proven to be a big success, why has the Commission not created other special rapporteurships, working full-time and also financed by private contributions? The SRFE has been functioning for fifteen years and the Commission has not created other special rapporteurships fully funded by external contributions and not by the Commission's limited budget.

On the other hand, the success of the SRFE could be explained by the receptiveness of the donors. As seen above, it seems that donors are inclined to support this particular rapporteurship more than the others. If that is the case, the ones that truly decide where the attention should be, or at least the degree of this attention, are the donors, not the Commission. This may be a good motive why Ecuador considers that the Commission's impartiality or independence could be affected. At first sight, the Ecuadorian concerns seem a little excessive, but a closer view may reveal that such concerns are not without basis. The SRFE is a very active office and has done the job it was expected to do. There has been no sign of influence of external sources in the SRFE conclusions or recommendations. This office is like an engine and the budget is its fuel. If the machine has enough fuel, it will do the tasks it was built to do. Without the fuel, it will stop. But fueling the machine is the issue that should be looked at with more caution. The fuel comes from donors whose intentions could be quite philanthropist or the opposite, with a hidden agenda. 
Consequently, Ecuador's proposals on the functioning of the Commission's rapporteurships, approved by the Working Group and by the Permanent Council, seem reasonable. If donors truly want to contribute to the promotion and protection of human rights in the Americas, they should not specify the purpose of their voluntary contributions; rather, the Commission should be the body to assign the resources to all its rapporteurships in an adequate, sufficient, and balanced way, according to needs it has identified in the region. Again, the Commission, not the donors, should decide how to address the human rights situation in the region. Evidently, the OAS Member States, Ecuador included, are primarily responsible for giving enough fuel to all the protection mechanisms the Commission has; yet until this goal is achieved, the recommendations of the Working Group should be taken seriously.

\section{The Working Group's RECOMMENDATIONS AND THE Commission's Response}

The Working Group recommended that the Commission: a) include clear and accessible information in its Annual Report on the management of the resources it receives; b) invite donors to make their voluntary contributions without specifying how the funds should be used until the Inter-American System is sufficiently funded; c) assign adequate, sufficient, and balanced resources to all its rapporteurships, working groups, and units; and d) incorporate all rapporteurs' reports under a single chapter of the Commission's Annual Report. ${ }^{36}$

The Commission responded to these suggestions on October 23, 2012. ${ }^{37}$ The Commission was willing to adopt certain measures in concurrence with the recommendations, but there is no indication that freedom of expression's preferential treatment will cease in the near future. For instance, although the Commission has already created a "basket" or common fund to provide an incentive for financing its activities, ${ }^{38}$ the rapporteurships will still be free to seek external donations. As such, the funding of the rapporteurships will continue to depend on the donors' will and intentions. ${ }^{39}$ In fact, the Commission has openly recognized that in the event a Member State or a permanent observer "from the start, establishes thematic priorities for which its funds are to be used, the [Commission] will accept them provided that the thematic objective coincides with its strategic priorities and previously established action plans." 40 Secondly, the Commission recognized the importance of transparent management. It offered to include all budgetary information in its Annual Report broken down by (i) source of financing, (ii) whether regular fund or specific funds, and (iii) item expenditure ${ }^{41}$ However, this information is already available on the Commission's website. ${ }^{42}$ Sadly, the information released by the Commission is not classified by rapporteurships. External observers cannot compare how much each rapporteurship receives and who is financing them. On the SRFE's website, there is no concrete information either, ${ }^{43}$ and in the SRFE's latest Annual Report only the donors are mentioned, but not the amount they contributed. ${ }^{44}$ Finally, there is no indication that the Commission is going to increase the personnel of the regular rapporteurships or balance the number of hearings, in loco visits, or other rapporteurship activities, nor the number of cases these offices will to refer to the Court. Nor is there is any indication that the Commission is planning to transform the SRFE into a regular rapporteurship under the supervision of a commissioner elected by the OAS Member States. Moreover, if the mechanism of special rapporteurs is going to be maintained, there is no indication that the Commission is planning to create new special rapporteurships to cover other rights different from freedom of expression or that the SRFE will cease in the near future, giving the floor to another right. In sum, freedom of expression will continue to be the king of rights in the Americas.

\section{The Code of Conduct}

The Working Group recommended that the Commission "[i]ntroduce a code of conduct to govern the management of [the Commission's] rapporteurships in order to ensure the requisite coordination between those mechanisms and states[.]" ${ }^{45}$ According to some, the code implies greater state control over the different rapporteurships ${ }^{46}$ or it could prevent the SRFE from publishing press releases that allegedly upset countries such as Venezuela and Ecuador. ${ }^{47}$

These positions seem to ignore that the Commission's Rules of Procedure already stipulate that " $[t]$ he activities and functions provided for in the Rapporteurships' mandates shall be performed in accordance with the present Rules of Procedure and the guidelines, codes of conduct and manuals that the Commission might adopt[.]"48 In other words, the Working Group's recommendation basically requires a policy the Commission has already partially enacted. It should also be highlighted that the Working Group's recommendation is directed toward the Commission and not the States; that is to say, the Commission is the one that should introduce the code of conduct and not Ecuador, Venezuela, or any other country. Naturally, it is expected that the Commission make space for an ample debate between the States and civil society organizations before it adopts such a code. This seems to be the Commission's intention. ${ }^{49}$

As to the press releases that "upset" countries such as Ecuador, one case may explain the Ecuadorian confrontation with the SRFE, but may justify the need for a Code of Conduct.

\section{The El Universo Case}

On July 20, 2011, a judge in Ecuador issued a judgment against the newspaper El Universo, three members of its board of directors, and one editorialist, all as a result of a defamatory publication of a column in the newspaper that offended President Rafael Correa and upset many Ecuadorians. The judgment sentenced the board members and the editorialist to three years in prison and the payment of a total of USD \$30 million. The legal entity that owns the newspaper was also sentenced to a fine of $\$ 10$ million. 
The next day, the SRFE issued a press release expressing its concern regarding the El Universo judgment. However, the SRFE did not limit itself to express concern or to inform on the Inter-American and universal standards on freedom of expression. It made statements like the following:

The Office of the Special Rapporteur considers this decision contrary to regional freedom of expression standards and believes that it generates self-censorship and a notable chilling effect that impacts not only the individuals convicted but Ecuadorian society as a whole.

...

In addition, the decision of July

20 constitutes a grave warning to

any citizen or media outlet that has opinions or information about public officials that could be considered offensive, thus obstructing processes that are natural and necessary in any democracy.

...

For these reasons, the Office of the Special Rapporteur exhorts the State of Ecuador to adapt its domestic legislation and practice to existing doctrine and jurisprudence in the area of freedom of expression .... ${ }^{50}$

The alleged victims appealed the judgment and the case was sent to the Court of Appeals (Corte Provincial), which confirmed the criminal and civil judgment on September 20, 2011. On September 21, 2011, the SRFE issued a new press release stating the following:

The judicial decisions in question generate a palpable chilling effect on ideas or information that may offend the authorities, an effect which is incompatible with hemispheric freedom of expression standards. The self-censorship that results from these types of decisions impacts not only journalists and the authorities themselves, but all of Ecuadorian society.

...

Given the gravity of the judicial decision in question, the Office of the Special Rapporteur once again calls on the Ecuadorian State to bring its normative framework and institutional practices into compliance with inter-American standards in the area of freedom of expression. ${ }^{51}$

The alleged victims requested the intervention of the Supreme Court (Corte Nacional), which in February 2012 confirmed the decisions of the lower courts. The SRFE issued a joint press release with the UN Special Rapporteur on the Freedom of Opinion and Expression. ${ }^{52}$ This time the wording of the press release was much less confrontational than the previous ones, and both rapporteurs limited themselves to reminding the reader of international standards on freedom of expression. Perhaps this extra caution was the consequence of the involvement of the UN Special Rapporteur, but it is hard to tell with certainty by an outside observer.
After the Supreme Court of Ecuador confirmed the conviction, President Correa decided to pardon the offenders and the case was closed at the national level. ${ }^{53}$ No fine was collected and none of the accused spent a single hour in jail. The case, though, is still pending before the Commission, in the admissibility stage of the proceedings. However, the SRFE's July and September 2011 press releases were issued before the alleged victims exhausted local remedies and before any type of pronouncement of the Commission on the merits of the case. The SRFE clearly labeled the facts of the case as "contrary to freedom of expression standards," an obstruction to democracy, and a source of "chilling effects" on ideas or information. It also requested that the country adapt its practice and law to the Inter-American standards.

The SRFE's July and September 2011 press releases could be read as pre-judgments made outside the regular proceedings that the Commission has to follow in all individual petition cases. A rapporteurship should not be allowed to essentially declare a violation of human rights before the Commission decides the case. This is a basic due process rule to guarantee a forum's impartiality. ${ }^{54}$

The SRFE does not have a vote in the Commission's decision on its pending cases, but it does have a voice. The Special Rapporteur participates in the Commission's deliberations and hearings; the Rapporteur may pose questions to the parties and may even represent the Commission in the procedure before the Inter-American Court. In fact, all the freedom of expressionrelated cases, including El Universo, are processed in the office of the SRFE. Is Ecuador allowed to challenge the participation of the Special Rapporteur on Freedom of Expression in any matter involving the pending case of El Universo if the State considered that the SRFE pre-judged the case? It seems that in order to preserve the Commission's impartiality, the answer to this question should be in the affirmative.

The Rules of Procedure of the Commission do not answer all these questions. The Code of Conduct then seems to be necessary to fill this and other gaps. ${ }^{55}$

\section{Conclusions}

Ecuador may have had political motives when it presented its proposals to the Working Group but this does not necessarily mean that the proposals are unfounded. The practice of the Commission shows that there is no uniformity in the creation and mandate of its rapporteurships. Only one rapporteurship, the SRFE, is special and devoted to a single right, while all the others are regular and devoted to persons in situations of vulnerability. The Commission has never explained why the right to freedom of expression, and not other rights, deserves a special rapporteurship. The Commission's lack of resources does not explain why it has not decided to create other special rapporteurships that work full-time and search for private funding.

The disproportional treatment of human rights in the Commission's rapporteurship mechanisms produces at least 
three consequences. Firstly, the States that (may) have poor records on freedom of expression are more targeted than States that have poor records on other rights. Secondly, victims of violations of the right to freedom of expression have more space and attention than victims of violations of other rights. Finally, donors, not the Commission, seem to be the ones that decide which right receives more attention. The Commission needs more funding, but it also needs more balance.

Finally, the Code of Conduct suggested by Ecuador and the Working Group does not seem to be a preposterous idea. The
Commission itself recognized the need for a manual, guidelines, or code of conduct for its rapporteurships. Furthermore, aspects of the rapporteurship's functioning, such as the content of their press releases, seem to lack sufficient regulation.

In short, Ecuador may have had a hidden agenda, but the Commission is the one supplying Ecuador with the ammunition used against it. If the Commission would explain better the process of creation, mandates, duration, and other aspects of its rapporteurships, Ecuador's proposals would have received less support.

\section{Endnotes}

1 Organization of American States [OAS], Permanent Council, Working Group, Record of the meeting of July 14, 2011, Doc. OEA/ Ser.G/GT/SIDH/SA.1/11 rev. 1 (July 18, 2011).

2 OAS, Permanent Council, Working Group, Final Report, Doc. OEA/Ser.G/GT/SIDH-13/11 rev. 2 (Dec. 13, 2011) [hereinafter Working Group, Final Report].

3 OAS, Permanent Council, Working Group, Compilation of Presentations by Member States on the Topics of the Working Group, Doc. OEA/Ser.G/GT/SIDH-17/11 rev. 1 (November 7, 2011).

4 See Special Working Group to Reflect on the Workings of the IACHR with a view to Strengthening the IAHRS, ORG. OF AM. STs. (Feb. 6, 2013), www.oas.org/council/workgroups/Reflect $\% 20$ on $\%$ 20Ways $\% 20$ to $\% 20$ Strengthen.asp (providing the collection of the various proposals).

5 OAS, Permanent Council, Working Group, Compilación de las recomendaciones de las organizaciones de la sociedad civil sobre los temas del Grupo de Trabajo, Doc. OEA/Ser.G/GT/SIDH-11/11 rev. 1 (Nov. 21, 2011).

6 Victoria Amato, Una mirada al proceso de reflexión sobre el funcionamiento de la Comisión Interamericana de Derechos Humanos, 16 ApORTES DPLF 4, 6 (2012); Observations on the Process of Reflection on the Workings of the Inter-American Commission With a View to Strengthening the Inter-American Human Rights Protection System, CEJIL (January 27, 2012), http:// cejil.org/en/comunicados/civil-society-observations-strengtheninginter-american-system (making accessible the Communiqué signed by 90 NGO's entitled "Civil Society Observations on the Strengthening of the Inter-American System); see also INTERAmerican Commission on Human Rights, Reform Process 2012 note 54, available at http://www.oas.org/en/iachr/strengthening/ docs/RespCPEn.pdf (issuing the "[r]eply of the Inter-American Commission on Human Rights to the Permanent Council of the Organization of American States regarding the recommendations contained in the Report of the Special Working Group to Reflect on the Workings of the IACHR with a View to Strengthening the Inter-American Human Rights System") [hereinafter Reply to the Commission].

7 See infra note 9.

8 OAS, Permanent Council, Working Group, Proposals by the Delegation of Ecuador, Doc. OEA/Ser.G/GT/SIDH/INF.46/11 (Dec. 5, 2011).

9 La OEA le da otro golpe a la libertad de expresión. EL Colombiano (Jan. 26, 2012), http://www.elcolombiano.com/ BancoConocimiento/L/la_oea_le_da_otro_golpe_a_la_libre_ expresion/la_oea_le_da_otro_golpe_a_la_libre_expresion.asp; Zarpazo a libertad de expresión. El UnIVERSAL (Jan. 17, 2012), http://www.eluniversal.com.co/cartagena/editorial/zarpazo-libertad-deexpresion; Laura Gil, Estocada a la CIDH. El TiEmPo (Jan. 26,
2012), http://m.eltiempo.com/opinion/columnistas/lauragil/ el-consejo-permanente-de-la-oea/11009181.

10 Working Group, Final Report, supra note 2.

11 Press Release, OAS Permanent Council Approved the Report of the Working Group to Strengthening the Inter-American Human Rights System. OAS Press Release No. E-018/12 (Jan. 25, 2012).

12 OAS, General Assembly, Follow-up on the recommendations contained in the "Report of the Special Working Group to Reflect on the Workings of the Inter-American Commission on Human Rights with a View to Strengthening the Inter-American Human Rights System," AG/RES. 2761 (XLII-O/12) (June 5, 2012).

13 Gobierno acusa a CIDH de parcialidad en caso del diario El Universo, EL Hoy, Feb. 22, 2012, http://www.hoy.com.ec/ noticias-ecuador/gobierno-acusa-a-cidh-de-parcialidad-en-casodel-diario-el-universo-535688.html.

14 Rules of Procedure of the Inter-American Commission of Human Rights, art. 15(2), Sept. 2, 2011 [hereinafter Rules of Procedure].

15 Id. art. 15(3).

16 Annual Report 1998, Inter-Am. Comm'n H.R., Doc. OEA/ Ser.L/V/II.102, doc. 6 rev. (1999) [hereinafter Annual Report 1998].

17 Organization of American States, American Convention on Human Rights, Nov. 22, 1969, O.A.S.T.S. No. 36, 1144 U.N.T.S. 123 [hereinafter American Convention].

18 Statute of the Inter-American Commission on Human Rights, O.A.S. Res. 447 (IX-0/79), O.A.S. Off. Rec. OEA/Ser.P/IX.0.2/80, Vol. 1 at 88 (Oct. 1, 1979).

19 History, ORg. of Am. Sts., www.cidh.oas.org/relatoria/ showarticle.asp?artID=52\&IID=1 (last visited Feb. 6, 2013).

20 Rules of Procedure, supra note 14, art. 15(4).

21 Annual Report 1998, supra note 16.

22 Rapporteurship on Human Rights Defenders, ORG. OF Aм. STs. (Feb. 6, 2013), http://www.oas.org/en/iachr/defenders/default.asp.

23 However, more research is needed in order to conclude that the SRFE is in fact addressing all the aspects of freedom of expression. It seems that the main focus of the SRFE has been the violations of this right produced by State actors, while violations produced by private actors seem not to be studied enough, for instance the restrictions imposed by media owners to the journalists that work for them, or the conscious release of erroneous information by the media, that affects the right of individuals to receive truthful information. 24 However, the Commission did recently create a Unit for the Rights of Lesbians, Gays and Trans, Bisexual and Intersex Persons. See Rights of Lesbian, Gay, Trans, Bisexual, and Intersex Persons, OrG. OF Am. STS., http://www.oas.org/en/iachr/lgtbi (last visited Feb. 6, 2013).

25 Vienna Declaration and Programme of Action, 1 5, adopted by the World Conference on Human Rights on 25 June 1993, U.N. Doc. A/CONF.157/23. 
26 Some authors consider that there is an emerging hierarchy of human rights, which is based on the non-derogable character some rights have in international human rights law. The right to freedom of expression seems not to be in such category of non-derogable rights. See Koji Teraya, Emerging Hierarchy in International Human Rights Law and Beyond: From the Perspective of Non-Derogable Rights, 12 Eur. J. INT'L L. 917 (2001).

27 Alexander H.E. Morawa, Vulnerability as a Concept of International Human Rights Law, 6 J. InT'L Rel. \& Dev. 139, 139 (2003).

28 OAS, Inter-American Commission, SRFE, Report of the SRFE 2010, Doc. OEA/Ser.L/V/II./Doc. 5, March 4, 2011, at 22 [hereinafter Report of the SRFE 2010].

29 Rapporteurship on the Rights of Migrants, INTER-AM.

Commission, http://www.cidh.oas.org/Migrantes/migrants.team.htm (last visited Feb. 6, 2013).

30 Rapporteurships Distribution, Org. Am. STS., http://www.oas. org/en/iachr/mandate/composition.asp\#tab3 (last visited Feb. 6, 2013).

31 OAS, Inter-American Commission, Annual Report 2010, Doc.

OEA/Ser.L/V/II/Doc.5, rev. 1, March 7, 2011.

32 Report of the SRFE 2010, supra note 28.

33 OAS, Permanent Council, Working Group, Proposals by the Delegation of Ecuador, Annex 1, Specific Funds received by the Rapporteurships of the Inter-American Commission on Human Rights in 2010, Doc. OEA/Ser.G/GT/SIDH/INF.46/11, December 5, 2011 available at http://scm.oas.org/pdfs/2011/CP27705S.pdf.

34 Organization of American States, Inter-American Commission on Human Rights: Strategic Plan 2011-2015, available at http:// www.oas.org/en/iachr/docs/pdf/IACHRStrategicPlan20112015.pdf. It should be noted that the presentation of the plan regarding the work of the thematic rapporteurships is divided in two sections: one for the seven regular rapporteurships and one just for the SRFE. 35 See Oswaldo Ruiz-Chiriboga, The American Convention and the Protocol of San Salvador: Two Intertwined Treaties. NonEnforceability of Economic, Social and Cultural Rights in the Inter-American System, NetH. Q. Hum. RTS. (forthcoming, available at http://papers.ssrn.com/abstract=1940559) (concerning the nondirect enforceability of ESC rights).

36 Working Group, Final Report, supra note 2, at 9, 16.

37 Reply of the Commission, supra note 6.

38 Id. ๆ 192.

39 Id. $198-99$.

40 Id. $\uparrow 196$.

41 Id. ๆ 189-91.

42 Financial Resources, ORg. Am. STS., http://www.oas.org/en/ iachr/mandate/financial_resources.asp (last visited Feb. 6, 2103).

43 Freedom of Expression: Financial Support, ORG. Ам.

STS., http://www.oas.org/en/iachr/expression/showarticle. asp? artID=105\&lID=2 (last visited Feb. 6, 2013).

44 OAS, Annual Report of the Office of the Special Rapporteur for Freedom of Expression, OEA/Ser.L/V/II. Doc. 69, December 30, 2011, at 978 .
45 Working Group, Final Report, supra note 2, at 15.

46 IFEX-ALC calls for withdrawal of three recommendations that impact on mandate of free expression rapporteur, IFEX, (Jan. 11, 2012), http://www.ifex.org/americas/2012/01/11/rapporteur_ recommendations.

47 La CIDH se juega su suerte EL TIEMPO, January 21, 2012 (translation of the author).

48 Rules of Procedure, supra note 14, art. 15(7) (emphasis added).

49 In its Response to the Permanent Council of the OAS, supra note 6 , 187, the Commission stated: "Given the importance of this matter, as well as the above-mentioned background to the subject, the IACHR requested in its recent consultations with users of the IAHRS that they comment on, inter alia, the "criteria and procedures for improving coordination between the IACHR and its rapporteurships with players in the system with respect to promotion[.]" The existence of rules and practices applying to the work of the rapporteurships will enable the IACHR to compile and publish a manual or set of instructions systematizing them, in such a way as to enhance predictability for all actors in the system and thereby improve coordination with respect to promotion. In that way, it will be possible to achieve the objective of "documenting and clearly disclosing the applicable rules and practices that establish the procedures and duties that are binding for the rapporteurs" (emphasis added). 50 Press Release, Special Rapporteur for Freedom of Expression, Office of the Special Rapporteur Expresses Profound Concern Regarding Conviction of Journalist, Directors and Media Outlet in Ecuador, OAS Press Release R72/11 (July 21, 2011) (emphasis added). 51 Press Release, Special Rapporteur for Freedom of Expression, Office of the Special Rapporteur Expresses Concern Regarding Confirmation of Conviction Against Journalist, Directors and Media Outlet in Ecuador, OAS Press Release R104/11 (Sept. 21, 2011) (emphasis added).

52 Press Release, Special Rapporteur for Freedom of Expression, UN and IACHR Special Rapporteurs for Freedom of Expression State Deep Concern over Decision to Affirm Judgment against Journalists in Ecuador, OAS Press Release R20/12 (Feb. 16, 2012). 53 Ecuador President Correa Pardons Paper in Libel Case, BBC, February 27, 2012, http://www.bbc.co.uk/news/world-latin-america-17177646.

54 Impartiality demands that a conflict-resolution body acting in a specific dispute approaches the case subjectively free of all prejudice and offering sufficient elements of conviction to exclude any legitimate misgivings or well-grounded suspicion of favoritism to one party. See Apitz-Barbera et al v. Venezuela, Preliminary Objections, Merits, Reparations, and Costs, Judgment, Inter-Am. Ct. H.R. (ser. C) No. 182, ๆ 56 (Aug. 5, 2008).

55 But see Instituto de Defensa Legal et. al., Organizaciones de sociedad civil de las Américas presentan su posición sobre el informe final elaborado por el Grupo de Trabajo Especial de Reflexión sobre el Funcionamiento de la CIDH para el Fortalecimiento del SIDH, 16 ApORTES DFLF 54, 56 (2012). 